\title{
Development of Entrepreneurial Competencies of Employees within the Framework of internal Entrepreneurship Programs in the Region
}

\author{
Anastasiya Pesha ${ }^{1}$, Marina Shavrovskaya ${ }^{1, *}$, Oksana Borodina $^{2}$ \\ ${ }^{1}$ Ural State University of economics, Department of labour economics and HR management, 8 Marta 62, 620144 Yekaterinburg, Russia \\ ${ }^{2}$ Omsk State University, Department of Regional Economics and Human Resource Management, Mira Avenue, 55-A, 644077 Omsk, \\ Russia
}

\begin{abstract}
The global economic environment is becoming more active and complex. Technological and social changes affect the internal processes of companies associated with the diversification of production, the introduction of new lines of products and services, the modernization of business processes. In this article, the authors present the results of a study into the ways ten large industrial companies (fuel, chemical and petrochemical, food industry, defence industry and agricultural technology) in the Omsk region develop domestic internal entrepreneurship. As a result of narrative interviews with HR directors of the selected companies, the authors formulated two approaches to the development of internal entrepreneurship. The first method is based on the development of a creative environment that stimulates the generation of initiatives to improve business. The second method involves companies implementing business projects through employee development programs. The advantages and disadvantages of both methods are subsequently highlighted. The conclusions draw attention to the problems of the development of internal entrepreneurship within large industrial companies and the need to create a special environment and infrastructure to promote the business initiatives of employees.
\end{abstract}

Keywords: entrepreneurial competencies; internal entrepreneurship; personnel; bank of ideas; innovation

\section{Introduction}

Many companies around the world pay great attention to attracting and developing internal entrepreneurship to maintain their competitiveness. The entrepreneurial spirit of employees determines the implementation of innovations in the company's activities and the maintenance of business sustainability in a rapidly changing economic and social reality $[1,2]$. The foundations of the concept of internal entrepreneurship were laid by scientists such as Macrae (1976), Nielsen, Peters and Hisrich (1985), Vesper (1984), Pinchot (1985) and others [1, 3, 4, 5]. Three decades ago, the founders of the concept noted that internal entrepreneurship was the main driver of large-scale changes in business and the economy.

Over the past 10 years, the number of studies in the field of entrepreneurial competencies in general and internal entrepreneurship in particular has been increasing. According to WoS data, the number of publications on the subject of this paper (the search term "intrapreneurship") increased more than 4 times from 2010 to 2019 (from 14 publications in 2010 to 61 publications in 2019). Today, new concepts of internal entrepreneurship are emerging, which point to the need to study entrepreneurial competencies in terms of "potential" (opportunities for implementation in the field of entrepreneurship), and not only the "capital" (availability of special education and entrepreneurial experience) of a person $[6,7]$.

The hypotheses about a positive correlation between the effectiveness of internal entrepreneurship, the development of entrepreneurial competencies and business growth and economic effect [8] are derived from and supported by empirical data [7]. Companies focused on engaging employees in innovative internal corporate behaviour should create an organizational climate that promotes entrepreneurial initiatives. The internal business climate, which is characterized by a "positive correlation between management support, remuneration system and employee autonomy", seeks to tap into employee innovation and to transform initiatives into real goods and services [9]. New ways of working (NWW), which involves internal competitions for the development of a culture of initiative and innovation within a company, enables employees to gain recognition for their work and for their importance to the company. Within this context, the culture and conditions for the manifestation of initiatives within an organization have a significant impact on the development of internal entrepreneurship $[6,10]$. As a result of the activities of internal entrepreneurs, new products and services are

\footnotetext{
${ }^{*}$ Corresponding author: marina_bel@list.ru
} 
introduced, new internal corporate companies are established, new markets and business development horizons are opened $[11,12,13]$.

Many large Russian companies are currently paying attention to the development of domestic internal entrepreneurship, realizing that in this area there are significant reserves for increasing productivity and labour efficiency $[14,15]$. In Soviet times, companies had systems for submitting and implementing innovation proposals, which helped to improve business processes. During the years of Perestroika, the system almost disappeared. However, it is now being revived because many companies understand the key role the level of entrepreneurial competencies of their employees plays.

The management of industrial companies based on internal entrepreneurship has been studied in the scientific works of authors such as Bukhvalov, Molodchik, Popov and Pustovojt (2012) and Dondokova (2004) [16, 17]. Industrial companies, like many others, need to create a special environment and infrastructure for the development of internal entrepreneurship, which facilitates the manifestation and implementation of business initiatives.

\section{Methodology}

The article presents the results of research into the practice of developing internal entrepreneurship in ten large industrial companies (fuel, chemical and petrochemical, food industry, defence and agricultural engineering) in the Omsk region, which are highlighted on the website of the city administration https:/www.admomsk.ru. The authors analyse existing approaches to the development of internal entrepreneurship in industrial companies, which are the main employers of graduates and the main providers of internships for students. The main goals of this work are to present and analyse the existing approaches to the development of internal entrepreneurship of companies in the region, as well as to highlight their advantages and disadvantages.

The method of collecting information was a narrative interview with HR specialists who are responsible for the development of internal entrepreneurship in their respective company, as well as for the collection, analysis and implementation of employee initiatives and/or projects. This method allowed us to collect qualitative data, which were further analysed and grouped into existing approaches to the development of internal entrepreneurship among employees.

The authors selected HR specialists in those companies where this work is carried out (for various reasons, many Omsk companies are not engaged in the development of internal entrepreneurship, despite the fact that in Soviet times they had a system for submitting innovation proposals). In addition, not all companies are allowed to disclose information about existing business processes, so only those HR specialists who could share tools for developing internal entrepreneurship participated in the interviews.

During the interview, it was important for the authors to get answers to the following questions:

1. How is the work on getting initiatives from employees organized?

2. How are employees involved and motivated to take the initiative?

3. What criteria are used to make a decision on whether an initiative will be implemented or not?

4. What advantages and disadvantages are there in the approaches to the development of internal entrepreneurship?

In addition, document analysis was used as a method. In total, half of the companies were able to share standards or presentations that describe systems for collecting initiatives from employees, their method of evaluation, and the methods used by the companies to motivate employees to submit them.

\section{Results and Discussion}

To study the features of the work on the development of internal entrepreneurship at industrial companies in the Omsk region, two main approaches were identified.

\subsection{Development of a creative environment that stimulates the generation of initiatives}

An industrial company is usually a well-established and stable structure that is difficult to quickly rebuild or break. However, by tradition, such organizations have their own systems that encourage various improvements and innovations. Some companies pay a fixed amount of money to initiators of changes in production, others build systems such as "The factory of initiatives", "The bank of initiatives", "The pipeline of initiatives", and so on. These are tools for improving the efficiency of a company by creating an environment for developing, reviewing and implementing employee initiatives.

The structure of such systems usually contains two basic elements - an administrator who receives, registers and curates ideas, and an initiative committee, which reviews, evaluates, makes a decision and summarizes the results of their implementation.

The functioning of this system is approximately the same everywhere and consists of several stages: 
1. The author of the initiative formulates and submits it in a certain way in the company. Some organizations require the initiator to write down their idea and bring it to the responsible person, whereas others have special boxes for collecting them, whilst the most advanced companies may use corporate portals or groups in messenger or on social networks.

2. The administrator registers the initiative. A number of companies have developed special classifiers for this purpose. There is an instruction for classifying and maintaining a register of initiatives in one of the studied companies.

3. An initiative is sent for evaluation to experts of relevant departments. A special methodology for evaluating initiatives has been developed at one of the military-industrial companies. At this stage, the initiative can be refined or combined with other ones that are similar in content. At this stage, initiatives can either be screened out, finalized or justified.

4. The revised initiative is sent to the finance department, where the economic effect is evaluated. At this stage, the idea's passport is formed and issued.

5. At a committee meeting of experts, the initiative is evaluated, ranked and a decision subsequently made on its implementation. By consolidating the experience of various industrial companies, the authors developed a matrix of criteria for evaluating initiatives based on their usefulness and availability.

Table 1. Criteria for evaluating initiatives

\begin{tabular}{|c|c|c|c|}
\hline \multirow{2}{*}{ Criterion } & \multicolumn{3}{|c|}{ Scores } \\
\hline & 1 & 2 & 3 \\
\hline \multicolumn{4}{|c|}{ Usefulness } \\
\hline $\begin{array}{l}\text { Compliance } \\
\text { with company's } \\
\text { strategy }\end{array}$ & $\begin{array}{l}\text { The initiative is useful for achieving } \\
\text { business goals, but not relevant in } \\
\text { the short term (1-3 years) }\end{array}$ & $\begin{array}{l}\text { The initiative corresponds to the } \\
\text { organization's strategy, but its } \\
\text { implementation does not affect the } \\
\text { achievement of the company's } \\
\text { priority goals }\end{array}$ & $\begin{array}{l}\text { The initiative corresponds to the } \\
\text { organization's strategy, and its } \\
\text { implementation affects the } \\
\text { achievement of the company's } \\
\text { priority goals }\end{array}$ \\
\hline $\begin{array}{l}\text { Expected } \\
\text { economic effect }\end{array}$ & Less than RUB 50,000 & From RUB 50,000 to RUB 500,000 & More than RUB 500,000 \\
\hline $\begin{array}{l}\text { Probability of } \\
\text { achieving the } \\
\text { expected result }\end{array}$ & $\begin{array}{l}\text { Probability of achieving the } \\
\text { expected result is less than } 30 \%\end{array}$ & $\begin{array}{l}\text { Probability of achieving the } \\
\text { expected result is from } 30 \% \text { to } 80 \%\end{array}$ & $\begin{array}{l}\text { Probability of achieving the } \\
\text { expected result is more than } \\
80 \%\end{array}$ \\
\hline $\begin{array}{l}\text { Impact on } \\
\text { business } \\
\text { processes }\end{array}$ & $\begin{array}{l}\text { Implementation of the idea will } \\
\text { affect one category of business } \\
\text { processes }\end{array}$ & $\begin{array}{l}\text { Implementation of the idea will } \\
\text { affect two or more categories of } \\
\text { business processes }\end{array}$ & $\begin{array}{l}\text { Implementation of the idea will } \\
\text { affect the results of the } \\
\text { company as a whole }\end{array}$ \\
\hline $\begin{array}{l}\text { Influence on } \\
\text { company's } \\
\text { image }\end{array}$ & $\begin{array}{l}\text { A significant impact on the } \\
\text { company's image }\end{array}$ & $\begin{array}{l}\text { There is an impact on the formation } \\
\text { of a positive image of the company } \\
\text { in the "eyes" of one of the } \\
\text { interaction groups (the state, } \\
\text { consumers, employees, including } \\
\text { potential ones) }\end{array}$ & $\begin{array}{l}\text { It will influence the formation } \\
\text { of a positive image of the } \\
\text { company in the "eyes" of more } \\
\text { than one of the interaction } \\
\text { groups (the state, consumers, } \\
\text { employees, including potential } \\
\text { ones) }\end{array}$ \\
\hline \multicolumn{4}{|c|}{ Availability } \\
\hline $\begin{array}{l}\text { Financial } \\
\text { resources }\end{array}$ & $\begin{array}{l}\text { The initiative requires an increase } \\
\text { in the current business plan }\end{array}$ & $\begin{array}{l}\text { The initiative requires a reallocation } \\
\text { of resources between items, but } \\
\text { within the current business plan }\end{array}$ & $\begin{array}{l}\text { The initiative is implemented } \\
\text { within the current business plan }\end{array}$ \\
\hline $\begin{array}{l}\text { Human } \\
\text { resources }\end{array}$ & $\begin{array}{l}\text { It is necessary to organize the } \\
\text { interaction of departments more } \\
\text { than one functional block to } \\
\text { implement the idea }\end{array}$ & $\begin{array}{l}\text { The interaction of departments of } \\
\text { one functional block to implement } \\
\text { the idea }\end{array}$ & $\begin{array}{l}\text { The work of employees of the } \\
\text { profile division is enough }\end{array}$ \\
\hline $\begin{array}{l}\text { Administrative } \\
\text { resources }\end{array}$ & $\begin{array}{l}\text { The general manager plays the main } \\
\text { role }\end{array}$ & $\begin{array}{l}\text { The managing director plays the } \\
\text { main role }\end{array}$ & $\begin{array}{l}\text { The division head plays the } \\
\text { main role }\end{array}$ \\
\hline Time resources & $\begin{array}{l}\text { It will take six months or more from } \\
\text { the initiation of the idea to the result }\end{array}$ & $\begin{array}{l}\text { It will take three to six months from } \\
\text { the initiation of the idea to the result }\end{array}$ & $\begin{array}{l}\text { It will take less than three } \\
\text { months from the initiation of } \\
\text { the idea to the result }\end{array}$ \\
\hline
\end{tabular}

Source: Authors.

When an Initiative (I) is evaluated according to two criteria, with scores for the two parameters usefulness and availability, it is assigned to one of four categories (see Figure 1):

- A - implementation zone (high availability and high usefulness);

- B - decision-making zone (high availability and low usefulness or low availability and high usefulness);

- $\mathrm{C}$ - rejection zone (low utility and low availability); 
In order to motivate employees to generate various initiatives, industrial companies use different systems. The main objectives of these systems are to:

- $\quad$ create an information base for generating initiatives;

- create a communicative and creative environment;

- $\quad$ create a positive image of the initiators;

- $\quad$ support initiatives and feedback.

All these systems can be classified into three groups:

1. Motivation to participate, whereby ideas are encouraged.

2. Motivation through results, whereby employees receive remuneration:

a. percentage of the economic effect of the implementation results;

b. fixed amount for each initiative.

\section{Availability}

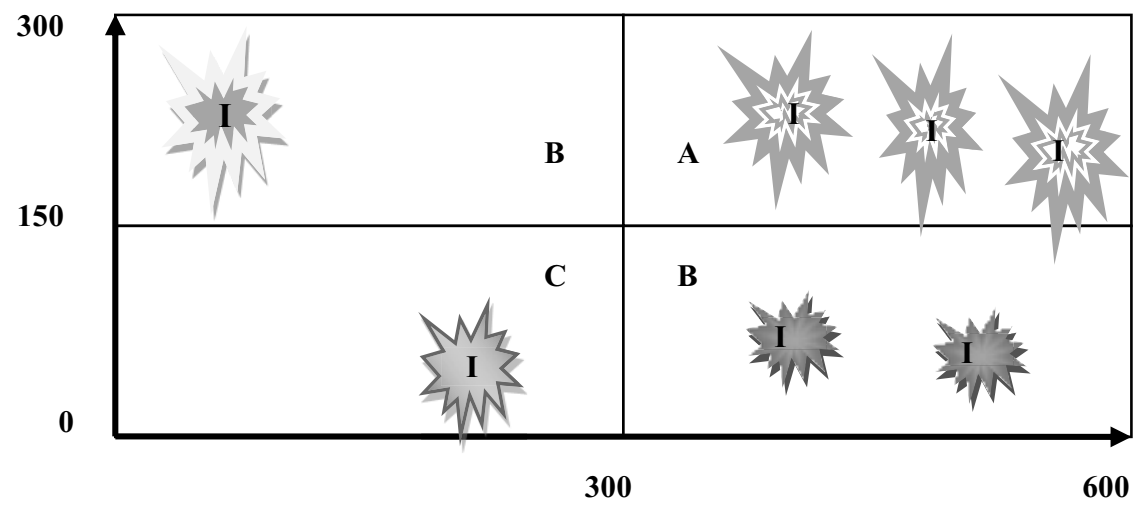

Usefulness

Figure 1. Evaluation of initiatives by expert committee

Source: Authors

3. Motivation through consolidation, whereby an employee is put in charge of the implementation of their own initiative, thereby creating an opportunity for career growth.

In several companies, the authors found interesting mechanisms to measure performance against the initiatives of its employees. By consolidating this information, three groups of performance indicators can be distinguished:

1. Employee engagement

a. engagement rates (number of initiators / number of personnel)

b. number of initiatives filed in a particular period $(\mathrm{N})$

2. Content of initiatives
a. areas of improvement (business process groups)
b. structure of initiatives by category $(\mathrm{A} / \mathrm{N}, \mathrm{B} / \mathrm{N}, \mathrm{C} / \mathrm{N})$
c. percentage of rejected initiatives

3. Performance
a. implementation rate (number of initiatives implemented / number of initiatives submitted)
b. coefficient of achievement of economic effect (factual savings / planned savings)
c. costs per 1 initiative ( $\sum$ costs / number of all initiatives)
d. potential coefficient (number of initiatives without investment / number of all initiatives)
e. total efficiency coefficient ( $\sum$ effects $/ \sum$ costs) 
The advantages of this approach are that:

1. all employees of the organization are involved in the process of generating ideas. Everyone has an equal opportunity to implement an initiative;

2. the environment for the development, review and implementation of initiatives of employees is formed within the company.

The disadvantages of this approach are that:

1. for large scale companies in the region, it is difficult to create an environment for the manifestation of entrepreneurial initiatives because of the large number of employees, structural divisions, difficulties in establishing communication processes, as well as the need to introduce additional jobs for organizing, planning and controlling the process;

2. the process from the inception of an idea to the assessment and implementation thereof is very long.

\subsection{Implementation of business projects through personnel development programs}

Without negating the value of the first approach, many industrial companies implement the initiative of internal entrepreneurship through personnel management. In this case, the promotion of business initiatives is implemented through training and development programs with a business focus. This may occur through, for example, the organization of corporate scientific and practical conferences for employees.

The main essence of this approach is that talents or initiators are assigned the task of developing and protecting a business project aimed at improving business processes or implementing business initiatives within the framework of developing corporate programs [18].

Employees can work on projects in small groups or alone. A mentor can join the project. As a rule, a certain period of time, for example a calendar year, is given to develop a business initiative. After the development stage, business projects are defended, winners are identified and rewarded, and the best ideas implemented.

This approach, in our opinion, has a number of advantages:

1. The talents within an organization are those with the potential to occupy a more responsible position. Members of the talent pool are ambitious, purposeful, innovative and ready to take steps to develop themselves and the company.

2. Project work is conducted usually in groups. When talented, high-potential employees interact, a synergy effect occurs and the output of promising business initiatives increases significantly (compared to the first approach).

3. Motivation to improve the business process and introduce initiatives for business development is a powerful tool for increasing employee engagement and loyalty, as well as the basis for creating an environment for the development of internal entrepreneurship.

The disadvantages:

1. The environment for the development of internal entrepreneurship is formed only in a few personnel (for example, in the talent pool) and participants of scientific and practical conferences. The participants of scientific and practical conferences are often talents.

2. Low risk tolerance of employees of Russian industrial companies. The fear of restrictions can become a stumbling block at the implementation stage of an employee's business initiative [19].

\subsection{Discussion}

For the development of internal entrepreneurship, it is necessary to create a certain environment, or even an ecosystem in a company $[9,17,20,21]$. The results of our research confirm the data of previous research on the importance of creating a supportive environment that includes, among other things, financial mechanisms, decision-making procedures, motivational and internal communication systems, and an innovative corporate culture. The key point is that the environment should promote the birth and development of internal entrepreneurs and the implementation of business initiatives. As the cases of the analysed companies show, internal initiative competitions can foster a culture of innovation in which employees can feel accomplished and receive recognition for presenting new ideas, as confirmed by the research of other scientists [10]. The relationship between a freely accessible open workplace and intrapreneurial behaviour is mediated by transformational leadership [6]. This area also needs to be studied by analysing the correlation between management styles in companies and the level of internal entrepreneurship.

Creating an environment for internal entrepreneurship should be accompanied by modernization of the industrial company infrastructure, including, among other things, technological equipment, financial support for initiatives and assessment of their investment attractiveness, and the training and development of employees' entrepreneurial competencies. While developing entrepreneurial competencies, it is important to pay attention to the employees' ability 
to assume responsibility for envisioning the necessary product, market, and management strategies [1]. Developing the ability of subordinates to take responsibility in Russian companies, where the authoritarian management style often prevails, is not such an easy task. In addition, it is rather difficult to teach people business thinking, which involves calculating risks and thinking about management strategies. Educational institutions should certainly assist in this by preparing graduates with a high level of entrepreneurial competence [22].

\section{Conclusion}

Internal entrepreneurship is not an innovation, its appearance in the last century is due to trends and features of economic development. At present, when the competition between industrial companies is strong and there is economic turbulence and dynamic technological development, internal entrepreneurship can become a strategic resource for a company's development. In this regard, the managements of companies should pay attention to creating an innovative internal corporate environment that promotes the involvement of a large number of employees in the process of developing business initiatives.

There are a number of problems associated with risk, independence, fear, financial support, and other factors on the way to implementing internal entrepreneurship. It is the shared opinion of the authors that the main obstacle to the development of internal entrepreneurship in industrial companies is the low level of development of employees' entrepreneurial competencies and the low level of involvement of people in the business processes of a company. In this area, we plan further research, in which we will try to identify areas of development in the studied companies and come up with a concept that will enable large industrial companies to successfully implement internal entrepreneurship.

\section{References}

1. G. Pinchot, Intrapreneuring: Why you don't have to leave the corporation to become an entrepreneur. University of Illinois at Urbana-Champaign's Academy for Entrepreneurial Leadership Historical Research Reference in Entrepreneurship (1985)

2. S. Veenker, P. V. D. W. SijdeDuring, A. Nijhof, Organisational conditions for corporate entrepreneurship in Dutch organisations. The Journal of Entrepreneurship. 17(1), 49-58 (2008)

3. N. Macrae, The coming entrepreneurial revolution: A survey. The Economist. 25, 41-46 (1976)

4. R. P. Nielsen, M. P. Peters, R. D. Hisrich, Intrapreneurship strategy for internal markets-corporate, non-profit and government institution cases. Strategic management journal. 6(2), 181-189 (1985)

5. K. H. Vesper, Three faces of corporate entrepreneurship - A pilot study. In J. A. Hornaday, F. Tarpley, Jr., J. A. Timmons, K. H. Vesper (Eds.) Frontiers of entrepreneurship research. Wellesley, MA. Babson College, 294326 (1984)

6. R. Gerards, S. van Wetten, C. van Sambeek, New ways of working and intrapreneurial behaviour: the mediating role of transformational leadership and social interaction. Review of Managerial Science. 1-36 (2020)

7. T. Lans, M. van Galen, J. Verstegen, H. Biemans, M. Mulder, Searching for Entrepreneurs among Small Business Owner-Managers. Proceedings of the ECER. (2010)

8. J. W. Hernandez Gonzalez, J. Diaz Castro, Intra Entrepreneurship Impact on Business Growth of MSMEs in the Tourism Sector in Villavicencio. Estudios Avanzados. 29, 75-85 (2018)

9. Z. Poduška, J. Nedeljković, D. Nonić, T. Ratknić, M. Ratknić, I. Živojinović, Intrapreneurial climate as momentum for fostering employee innovativeness in public forest companys. Forest Policy and Economics. 119 (2020)

10. J. R. Campos-Blázquez, P. Morcillo, L. Rubio-Andrada, Employee Innovation Using Ideation Contests: SevenStep Process to Align Strategic Challenges with the Innovation Process. Research-Technology Management. 63(5), 20-28 (2020)

11. C. Blanka, An individual-level perspective on intrapreneurship: a review and ways forward. Review of Managerial Science. 13(5), 919-961 (2019)

12. S. Kingma, New ways of working (NWW): work space and cultural change in virtualizing organizations. Culture and Organization. 25(5), 383-406 (2019)

13. J. C. Rigtering, G. U. Weitzel, K. K. Muehlfeld, Increasing quantity without compromising quality: How managerial framing affects intrapreneurship. Journal of Business Venturing. 34(2), 224-241 (2019)

14. E. A. Bubenok, Obosnovanie vedushchej roli intraprenerstva (vnutrennego predprinimatel'stva) i brendinga v obespechenii konkurentosposobnosti kompanij [Rationale for the leading role of intrapreneurship (internal 
entrepreneurship) and branding in ensuring the competitiveness of companies]. Vestnik Bryanskogo gosudarstvennogo universiteta. 3, (2014)

15. O. E. Ustinova, Korporativnoe predprinimatelstvo kak strategicheskiy resurs innovatsionnogo razvitiya kompanii [Corporate entrepreneurship as a strategic resource for innovative development of a company]. Voprosy innovatsionnoy ekonomiki. 10(2), 993-1006 (2020)

16. N. Y. Bukhvalov, A. V. Molodchik, V. L. Popov, K. S. Pustovojt, Upravlenie organizacionnymi innovaciyami na predpriyatii oboronno-promyshlennogo kompleksa [Organizational innovation management at the company of the military-industrial complex] Kreativnaya ekonomika. 10, (2012)

17. S. C. Dondokova, Upravlenie promyshlennym predpriyatiem na osnove vnutrennego predprinimatel'stva [Industrial company management based on internal entrepreneurship]. Doctoral dissertation, [Vost.-Sib. gos. tekhnol. un-t] (2004)

18. T. Keil, R. G. McGrath, T. Tukiainen, Gems from the ashes: Capability creation and transformation in internal corporate venturing. Organization Science. 20(3), 601-620 (2009)

19. A. Pesha, T. Kansafarova, Influence of the deficit of highly qualified personnel on the competitiveness and investment attractiveness of industrial companys. In The 12th International Days of Statistics and Economics. 1357-1366 (2018)

20. U. Cantner, J. A. Cunningham, E. E. Lehmann, M. Menter, Entrepreneurial ecosystems: a dynamic lifecycle model. Small Business Economics. 1-17 (2020)

21. P. G. Svensson, T. Q. Mahoney, Intraorganizational conditions for social innovation in sport for development and peace. Managing Sport and Leisure. 25(3), 220-238 (2020)

22. A. Y. Chepurenko, How and why to teach students entrepreneurship. Educational Studies. 3 (2017) 